\title{
THE HUMAN RIGHTS IN ISLAM \\ (The Study of Al-Muwafaqat by Imam Al-Syathibi)
}

\author{
Moch. Cahyo Sucipto \\ Prodi Perbankan Syariah STIES Indonesia Purwakarta \\ Jl. Veteran No 150-152 Ciseureuh Purwakarta Jawa Barat Indonesia
}

cahyosucipto@gmail.com

\begin{abstract}
The zhahiriyyah school is a school that stores certain texts by forgetting the global objectives of sharia. Among them there are those who are more dominant with the nature of religion, and among them there are those who are dominant in the nature of politics, even though they are all the same in terms of understanding literalism. The Zhahiriyya have been exaggerated in extracting text literalism to bring them to the strange understanding rejected by religion and reason. Zahiriyyah characteristics literal understanding and interpretation in understanding and interpreting texts without seeing things hidden in them, both in illat form and intentions that can be known by profound researchers: 1) Difficult and difficult; 2) Arrogant towards their opinions; 3) Don't accept different people; 4) Kafir people who have different opinions; 5) Whatever slander. The Bathiniyyah school is the opposite of the forgotten zhahiriyah school, even deliberately refusing, certain texts. This flow claims that they see the common good and global goals. This flow dares to oppose religious texts brought by the revelation ma`sum, both the Qur'an or al-Sunnah. They reject the text without caring, and freeze it without knowledge and guidance unless they follow the nature of themselves or others who want to make slander against the teachings of truth revealed by God. When they annulled religious texts in the name of human benefits. They claim that from these spies they are not out of the Shari'ah, they defend their intentions and maintain their spirit and substance, even though they do not maintain symbols and forms. Characteristics of the divine; 1) Superficial understanding of sharia `ah; 2) Dare to think without knowledge; 3) Follow westward. The third characteristic of the bathiniyyah school is to follow the other, west, both capitalism, liberalism or marix, all born in the west. From this they want to impose Western philosophy on the life, western views of religion, the concept of western scularism, and western, social, political, linguistic, and cultural legal theories for us. Some of them said, "we have to eat when they eat, dress when they are dressed, write when they write.
\end{abstract}

Keywords - Human Rights In Islam

\section{INTRODUCTION}

Mustafa Said al-Khin in his book al-Kafi al-Wafi fi Ushul al-Fiqh al-Islamy made a new breakthrough on the tendency of the flow in Ushul Fiqh Science. If previously known only two streams, namely Mutakallimin and fuqaha or Shafi'iyyah and Hanafiyyah, al-Khin divide it into five parts: Mutakallimin, Hanafiyyah, al-Jam'i, Takhrij al-Furu " alal Ushul and Syathibiyyah.

This division, the author's opinion, is the latest division in which the tariqah pursued by Imam Syathibi in alMuwafaqat becomes one part of the stream that is separate from other usul streams. Not exaggerated indeed, because in its style al-Syathibi tried to combine theories (nadhariyyat) Ushul Fiqh with the concept of Maqashid al-Shari'ah so that the resulting law products more alive and more contextual.

There is an important value, the writer thinks, if the model of al-Syathibi is developed by scholars now in digging the law, which can bridge between "right stream" and "left flow". The "right flow" in question is those who stick firmly to the concepts of Ushul Fiqh Science while the "left flow" is their last vowel with the idea of tajdid Ushul al-Figh in the sense of necessary reconstruction of Ushul Fiqh in order to produce more fiqh products capable.

With the methodology of Imam Syathibi in his alMuwafaqat trying to combine Ushul's theories with the Maqashid al-Shari'ah will be the bridge as well as the bridge to "wash" these two tendencies.

\section{RESULTS AND DISCUSSIONS}

A. Brief Biography of Imam al-Syathibi

Before explaining more about the biography of Imam Syathibi, it is necessary for the author to point out first that the book which deals specifically about the life of Imam Syathibi, to the knowledge of the author, there are two namely that ditahkik by Ustadz Muhammad Abu al-Ajfan: al-Ifadaat wa alInsyadaat li Syathibi and Fatawa al-Imam al-Syathibi. Then his student, Ahmad Baba Attanbakaty tried to further develop in his two works Nailul Ibtihaj and Kifayatul Muhtaj.

Imam Syathibi's full name is Abu Ishak Ibrahim ibn Musa ibn Muhammad Allakhami al-Gharnathi. He was born in Granada in $730 \mathrm{H}$ and died on Tuesday the 8th of Sha'ban in $790 \mathrm{H}$ or $1388 \mathrm{AD}$. The name Syathibi is a nisbat to the birthplace of his father in Sativa (Syathibah = arab), an area east of Andalusia. In 1247 AD, the family of Imam Syathibi fled to Granada after Sativa, his place of origin, fell into the hands of the king of Spain Uraqun.

Granada itself was originally a small town located at the foot of a very thick Syulair mountain with its snow. When the Syathibi priest lives, Granada is ruled by the Bani Ahmar. Bani Ahmar itself is the name for the descendants and family Sa'ad bin Ubadah, because it has a reddish skin color. The Spaniards call Abu Sa'ad this with al-Barmekho which in Spanish means the color of a reddish orange.

When the Bani Ahmar came to power, people's lives were far from Islamic life and even they were filled with various khurafat and bid'ah. Because the clerics of that time had little background on religious matters, this condition became worse when Muhammad al-Khamis who held al-Ghany Billah held power. 
It was then that Imam Syathibi rose up against and against the scholars of Granada at the time. He tried to straighten and restore the heresy to the sunnah and bring the people from heresy to the truth. The fierce bickering between Imam Syathibi and the Granada clerics was inevitable. Whenever the Imam Syathibi is kosher, they, on the other hand, have ill-willed without looking first at the texts. Therefore, Imam Syathibi was later harassed, reviled, excommunicated and considered to have departed from the true religion.

\section{B. The works of Imam al-Syathibi}

The works of Imam Syathibi all refer to two fields of science which, according to the term Hammadi al-Ubaidy, ulum al-wasilah and ulum al-maqasid. Ulum al-wasilah is the Arabic sciences which is a pure to understand the Science of Maqasid. For more details, here is a glimpse of the works of Imam Syathibi: 1. Kitab al-Muwafaqat. 2. Kitab al-I'tisham. 3. The Book of al-Majalis. 4. Sharah al-Khulashah. 5. Unwan alIttifaq fi 'Ilm al-Isytiqaq. 6. Ushul an-Nahw. 7. Al-Ifadaat wa al-Insyadaat. 8. Fatawa al-Syathibi. . Among the many works of this Imam Syathibi, printed only three namely Kitab alMuwafaqat, Kitab al-I'tisham and al-Ifaadat wa al-Insyadaat.

\section{About Al-Muwafaqat}

"Qalilun minka yakfiini wa lakin qaliluka la yuqalu lahu qalil". Thus one of the poems Rashid Rida expressed against the two works of Syathibi, namely al-Muwafaqat and alI'tisham in Muqaddimah Kitab al-I'tisham which he wrote. In fact he further gives two titles for the Imam Syathibi namely Mujaddid fi al-Islam with his Kitab al-Muwafaqat and alMushlih with his Kitab al-I'tisham.

It is proper that Imam Syathibi bears the two titles above because in al-Muwafaqat he attempts to renew the understanding of shari'ah by bringing the aqal to understand maqasid and the secrets contained therein. While in al-I'tisham he tried to restore the bid'ah to the sunnah and tried to offer the concept to build a community life in accordance with what is practiced in the time of the Prophet and al-Khulafa al-Rashidun.

Initially the book of al-Muwafaqat is entitled al-Ta'rif bi Asrar al-Taklif for revealing the secrets behind the law of taklif. But Imam Syathibi felt less fit with this name until one day he dreamed. In this dream Imam Syathibi meets one of his shaykhs, both walking and telling the story carefully. Then the teacher said to Imam Syathibi: "Yesterday I dreamed of seeing you carrying a book of your own. Then I asked you about the title of the book and you said that the title is al-Muwafaqat. I then asked the meaning again and you replied that you are trying to reconcile the two schools of Shafi'i and Hanafi ". After the dream, Imam Syathibi replaced it with the name al-Muwafaqat.

This book consists of 4 juz but viewed from the aspect of the theme is divided into 5 parts: 1 . Al-Muqaddimah (There are 13 problems described in this mukaddimah as a first step and basic in understanding the discussion of al-Muwafaqat next book). 2. Al-Ahkam (Discussing the five laws of taklifi and the five laws of wadh'i in addition are also explained in relation to maqasid al-Shari'ah). 3. Al-Maqasid (This discussion is discussed in juz II to complete.In this occasion the author will only dissect this chapter alone considering this issue which makes al-Muwafaqat soaring). 4. Al-Adillah (This chapter deals with two propositions namely al-Qur'an and al-Sunnah and other related laws such as naskh, amr, nahyi and others). 5 . Al-Ijtihad wa al-Tajdid (This chapter explores the issue of ijtihad and taqlid or better known as Ahkam al-Ijtihad wa alTaqlid).
The book of al-Muwafaqat was first recognized in Tunisia by Tunisian students and scholars of that time. Then for the first time printed in Tunisia in $1302 \mathrm{H}$ or $1884 \mathrm{M}$ in Mathba'ah alDaulah al-Tunisiyyah with tashih from the three great scholars of Tunisia at that time namely: Shaykh Ali al-Syanufi, Shaykh Ahmad al-Wartany and Shaikh Shalih Qayiji. While in Egypt only first printed in $1341 \mathrm{H} / 1922 \mathrm{M}$ or after approximately 38 years printed in Tunisia. Therefore, what Abdullah Darraz wrote in Mukaddimah al-Muwafaqat that this book was first printed in Egypt, becomes indisputable.

This book began to be known in Egypt since Muhammad Abduh made a visit to Tunisia in 1884M. From that visit Abduh then introduced him to Egypt and printed two prints first, first shot by Muhammad Muhyiddin Abdul Hamid (printed by Maktabah Shabih in Egypt in 1969M) and the second by Shaykh Abdullah Darraz (printed by al-Maktabah alTijariyyah al-Kubra in Egypt without years of printing).

Among the scholars who have a very important role in popularizing this book is Muhammad Abduh and his students Muhammad Rashid Rida and Rashid Ridha's student, Abdullah Darraz. Even Rashid Ridha sees this al-Muwafaqat book comparable to Ibn Khaldun's al-Muqaddimah

\section{History of Maqashid aL-Shari'ah}

Was it before Imam Syathibi Maqahid al-Shari'ah existed? This question is what the author wants to discuss in this sub chapter. It is true that Imam Syathibi is the first Maqashid alShari'ah as well as the founder of Maqashid Science, but that does not mean that there was no Maqasid Science before. Imam Syathibi is more aptly called the first person to systematically arrange the Maqashid al-Shari'ah as Sunni Imams according to the Sunnis with the science of Ushul Fiqhnya.

The word al-maqasid itself according to Ahmad Raisuni, first used by al-Turmudzi al-Hakim, scholars who lived in the 3rd century. He is, according to Raisuni, who first voiced the Maqashid al-Shari'ah through his books, al-Shalah wa Maqashiduhu, al-Haj wa Asraruh, al-'llah, 'Ilal al-Shari'ah,' Ilal al- ' Ubudiyyah and also his al-Furuq book which was later adopted by Imam al-Qarafi to be the title of his book.

After al-Hakim came Abu Mansur al-Maturidy (d333) with his Ma'khad al-Syara 'followed by Abu Bakr al-Qaffal alSyasyi (w.365) with his book Ushul al-Fiqh and Mahasin alSyari 'Ah. After al-Qaffal appeared Abu Bakr al-Abhari (w.375) and al-Baqilany (w.403) each with his work, among them, Mas'alah al-Answer wa al-Dalail wa al'llah and al-Taqrib wa al-Irsyad fi Tartib Thuruq al-Ijtihad.

After the death of al-Baqillany came al-Juwaeny, al-Ghazali, al-Razy, al-Amidy, Ibn Hajib, al-Baidhawi, al-Asnawi, Ibn Subuki, Ibn Abdishalam, al-Qarafi, al-Thufi, Ibn Taimiyyah and Ibn Qayyim.

The above sequence is Ahmad Raisuni's version, whereas according to Yusuf Ahmad Muhammad al-Badawy, the history of Maqashid al-Shari'ah is divided into two phases namely the phase before Ibn Taimiyyah and the phase after Ibn Taymiyyah.

According to Hammadi al-Ubaidy the person who first discussed the Maqashid al-Shari'ah was Ibrahim an-Nakha'i (w.96H), a tabi'in and his teacher Hammad bin Sulaiman his teacher Abu Hanifah. After that came al-Ghazali, Izzuddin Abdussalam, Najmuddin at-Thufi and last Imam Syathibi.

Despite the various versions, it can be concluded that before the Imam of Syathibi, Maqashid al-Shari'ah already existed and was known only the arrangement was not systematic so that the coming of Imam Syathibi. 


\section{E. Understanding Maqashid al-Shari ah}

Language, maqashid asy-syari'ah consists of two words, namely maqashid and syari'ah. Maqashid is a plural form, meaning intent or purpose. Shari'ah means language means the way to the source of water. The road to this water source can also be said to be the way to the ultimate source of life. Based on the etymology, maqashid al-syariah means the goals of sharia. In this case the purpose of shari'a is Allah and His Messenger in establishing Islamic law. As to the terminology, the concept of Maqashid asy-Shariah explains that the ultimate goal of law is the benefit and welfare of mankind. Among the verses that indicate that the purpose of the Islamic Shari'ah is the benefit is وما ارسلناك الا رحمة للعالمين.

According to Wahbah Zuhaili, maqashid asy-syariah means the values and targets of sharia implied from all or the greatest part of its laws. These values and objectives are regarded as the goals and secrets of sharia, established by sharia makers in all legal provisions. Maqashid as-shari'a, according to asy-syatibi can be seen from two points of view. First, judging from the point of the sharia maker; second, from the point of view of the mukalaf. Welfare which is the goal of sharia is limited in five things, namely religion, soul, mind, descendant and wealth. Each that contains the value of protection against the five things is called mashlahat, while the things that hinder it, even eliminating the five things is called mafsadat.

In al-Muwafaqat I / 38, II / 10, III / 10 and IV / 27 the order is as follows: ad-din (religion), an-nafs (soul), an-nasl (offspring), al- ) and al-aql (common sense). Whereas in alMuwafaqat III / 47: ad-din, an-nafs, al-aql, an-nasl and al-mal. And in al-I'tisham II / 179 and al-Muwafaqat II / 299: ad-din, an-nafs, an-nasl, al-aql and al-mal.

The above sequence differences show that everything is legitimate because of its ijtihadi nature. Other scholars of ushul have never agreed on this matter. For al-Zarkasyi for example, the order is: an-nafs, al-mal, an-nasab, ad-din and al-'aql. While according to al-Amidi: ad-din, an-nafs, an-nasl, al-aql and almal. For al-Qarafi: an-nufus, al-adyan, al-ansab, al-'uqul, alamwal or al-a'radh. Meanwhile, according to al-Ghazali: ad-din, an-nafs, al-'aql, an-nasl and al-mal. But this al-Ghazali's order is the most widely held sequence of the Fiqh and Ushul Fiqh scholars. In fact, Abdullah Darraz, pentahkik al-Muwafaqat himself, sees this version of al-Ghazali's sequence as closer to the truth.

\section{F. The flow of Maqashid al-Shari ah}

1. Zhahiriyyah

a. A glimpse of zhahiriyyah

The flow of zhahiriyyah is a school that holds particular texts by forgetting the global aims of shari'ah. Among them there are more dominant to the nature of religion, and among them there are dominant in the political nature, although they are all the same in terms of literalism of understanding. Some of them are actually drowned in their zhahiriyya, and some are in but not drowning.

Zhahiriyya has been exaggerated in extracting text literalism to bring them to strange understandings rejected by religion and reason. Although their cleric, Abu Muhammad bin Hazm, was a genius. An example is his opinion of the hadith of the prophet explaining the urine in the flowing water, "let no one of you urinate in the still water that does not flow, then bathe in it." While in one other narration, " inside ".

Ibn Hazm argues that people who urinate in silent water, do not flow, should not bathe or wudlu from the water. Good for other obligations. However, if urine does not change the water, it is halal in use for wudlu and bathing. Ibn Hazm refused to drink to the wudlu and wash. Thus, he allows drinking and forbidding wudlu and bathing.

b. Characteristics and characteristics of zahiriyyah

A literal understanding and interpretation Literal in understanding and interpreting texts without seeing the things that tersembnyi in it, both in the form of illat and intentions that can be in the know by a researcher deep.

1) Hard and difficult

While not acknowledging it, it is strict, strict and excessive. In fact, they argue that it is a truth that is in accordance with the proposition.

2) Arrogant to their opinion

They regard their opinion as absolute truth and regard other people's opinions as mistakes.

3) Do not accept people who differ

Do not accept the opinions of people who disagree with them, assuming that their right thoughts make them deny, even forcefully against those who disagree with them.

4) Disbelieve people who are different opinions

These literal people are not enough simply by denying those who disagree with them, but they do much greater than that, that is to make the mistake, to prophesy, to fertilize, and to disbelieve them.

5) No matter the slander

These traits and characteristics are coupled with a weak feeling towards others. In fact, the bias so, the feeling has been lost entirely.

\section{Bathiniyyah}

a. Overview of bathiniyyah

This stream is the opposite of the zhahiriyah stream that forgets, even deliberately rejects, certain texts. This stream claims that they look to the general maslahat and global purposes. this school is brave against religious texts that are brought by the revelation ma`sum, either al-Qur`an or alSunnah. They reject the texts without care, and freeze them with no knowledge and guidance except to follow the selfnature or others who want to make slander against the teachings of righteousness revealed by Allah. In fact, God wants people to take the whole truth and believe in the Qur'an. Unlike the children of Israel who was given the holy book.

The amazing thing is when they annull the religious texts under the name of human benefit. They claim that from this snoop they do not come out of shari'at, it defends its intentions and maintains its spirit and substance, though they do not preserve the symbols and shapes.

On behalf of maxims-shari'ah intent, they want to remove all fiqh and science ushul fiqh, and enough with the intent of syari at only. They extend the intentions of interpretations to give legality to liberalism, marxism, modernism, and postmdernism. All these trends can be justified in Islam with the names of shari'a intentions. In other words, we destroy the laws of shari 'a with the syari`at itself.

b. The characteristics and characteristics of the bathiniyyah

1) Superficial understanding of shari 'ah

Both a source, basis and fiqh fiat is so vast. They hardly understand the Qur'an any. Most, if not whole, of them can not read the Qur'an with the correct reading. They do not know the sciences of the Qur'an (ulum al-Qur'an) and do not read their interpretations. Whether in the form of tafsir history or dirayat. 
2) Dare to think without knowledge

With their ignorance of the foundations and sources of shari'at, they too dare to argue with no knowledge. We can see among those who speak and write a book about shari at, as if he is an Islamic shaykh or a mufti. In fact, the greatest sin in the sight of Allah is the one who speaks without knowledge.

3) Following the west

The third feature of the flow of the bathiniyyah is to follow the other, the west, either capitalism, liberalism or marix, all born in the west. From here they want to impose western philosophy in life, western view of religion, western concepts of skularism, and western theory of law, social, politics, language, and culture to us. One day among them some say, "we must eat as they eat, dress as they dress, nan write to kana as they write.

The First Al-Muta`ammiquna bi al-Qiyas a. At a glance the flow of al-Muta ammiquna bi al-Qiyas This flow is walking with moderate majhad for moderate people. He is in the middle between the two streams already in the forefront, he does not exaggerate like those who like to exaggerate and reduce like people who like to reduce. It is a straight flow that rejects both extremism. He believes in balance, justice and God's word. The characteristics and characteristics of al-Muta ammiquna bi alQiyas flow 1. Believe in the wisdom of syari at containing kemaslahatan Believe in the wisdom of shari 'ah that contains the benefit, everything that human needs, and things that can provide benefits and progress to humans. This is because the Shari'a is sent down the most knowing and wise. Thus, syari `at is a mirror of science and wisdom. 2. Combining text and shari'at law If one wishes to understand shari'at correctly, knowing the nature as it desires the one who descends it, exemplified by the prophet, and understood by the companions and those who follow them well, he can not see the text- and the laws are separate and scattered, 3. Viewing justly to the affairs of religion and the world One characteristic of this school is to look at the problems of the world and life with a balanced and fair view, it is neither exaggeration nor neglect.

The second Konfergensi or Thariqatu al-Jam i This flow is a stream that combines the three streams above, namely the flow of zhahiriyyah, the flow bathiniyyah and also the flow of al-Mutaammiquna bi al-Qiyas, so basically this flow tries to use all the three flow ways above. a. Maqashid al-Shari'ah According to Imam al-Syathibi Imam Syathibi discusses the Maqashid al-Shari'ah in his book al-Muwafaqat juz II as much as 313 pages (according to the printed book Dar al-Kutub alIlmiyyah). Issues raised in it as many as 62 problems. In his discussion, Imam Syathibi divides al-Maqashid into two important sections namely Shari'a Purpose '(qashdu al-syari') and Mukallaf Meaning (qashdu al-mukallaf). The meaning of Shari 'is then subdivided into 4 sections:

1. Qashdu al-Shari 'fi Wadh'i al-Shari'ah (syari's intention in deciding the Shari'a).

In this section there are 13 issues raised. But it all refers to a question: "What is Shari'a purpose by establishing its Shari'ah?" According to Imam Syathibi, Allah revealed the Shari'a (rule of law) is nothing but to take the benefit and avoid the maturity (jalbul mashalih wa dar'ul mafasid). In an easier language, the rules of law that Allah specifies are only for the benefit of man himself. Syathibi then divide this maslahat to three important parts namely dharuriyyat (primer), hajiyyat (skunder) and tahsinat (tertiary).
Maslahat Dharuriyyat is something that must exist for the realization of the benefits of religion and the world. If this does not exist, it will cause damage and even loss of life and life such as eating, drinking, praying, shaum and other worship. There are five (five) categories: religious (al-din), soul (alnafs), descendants (an-nasl), property (al-mal) and aqal (alaql). Before the author further explains the workings and afflictions of al-dharuriyyat al-khams, the writer must first submit the fifth order of this dharuriyyat either by Imam Syathibi or other ulama ushul. This is very important because it affects the legal conclusion to be generated.

The fifth order of this dharuriyyat is ijtihady not naqly, meaning it is composed based on the scholars' understanding of the texts taken by istiqra. In composing these five dharuriyyat (some call it al-kulliyyat al-khamsah), Imam Syathibi sometimes prefers aql rather than nasl, sometimes nasl first then aql and sometimes nasl then mall and last aql. But one thing should be noted that in any order the Imam Syathibi always begins with din and nafs first.

The workings of the five dharuriyyat above are each must be run in accordance with the order. Keeping al-din should take precedence over keeping the others; keeping al-nafs should take precedence over al-aql and nasl so on. One example that authors point out is that killing oneself or plunging into destruction is something forbidden. But if for the sake of jihad and the interests of the religion of Allah, be allowed because as has been mentioned above that keeping religion should take precedence than to keep the soul.

But what about the case of a sick person who because of a need for treatment may be seen by his / her aurat or a traveler who may pray, does not that mean an-nafs takes precedence over ad-din?

On this occasion the author will only quote Abdullah Darraz's opinion because it is more succinct. According to him that in general level religion should take precedence over others because it concerns ushul al-din, while in certain cases soul and property sometimes take precedence over religion (mustatsnayyat). Here is the need for a Mujtahid foresight.

Maslahah Hajiyyat is something that should exist in order to implement it freely and avoid the difficulties. If something is not there, then it will not cause damage or death will only lead to masyaqah and narrow. For example, in the matter of worship is the existence of rukhsah; shalat jama and qashar for the traveler.

Maslahah Tahsinat is something that should exist in accordance with the necessity of good morals or with custom. If something is not there, it will not cause damage or loss of something nor will cause the masyaqah in doing it, it's just considered inappropriate and inappropriate to manurut the size of manners and decency. Among the examples are thaharah, covering the aurat and the loss of unclean.

2. Qashdu al-Shari 'fi Wadh'I al-Shari'ah lil Ifham (Shari'ah's intention in establishing this shari'ah is to be understood).

This section is the shortest discussion because it only covers 5 issues. In establishing its Shari'ah, Shari'aims that mukallaf can understand it, that is the intent of the second part. There are two important points discussed in this section. First, this shari'ah is revealed in Arabic as His word in the letter of Joseph verse 2; as-Syu'ara: 195 . Therefore, to be able to understand it must first understand the ins and outs and uslub Arabic. In this case Imam Syathibi said: "Whoever wants to understand it, then he should understand from the Arabic tongue first Because without this it is impossible to understand 
it steadily. This is the subject of this discussion. " With the language easier, in addition to knowing Arabic, to understand the shari'ah is also required other sciences are closely related to oral Arabic such as Ushul Fiqh, Mantiq, Ma'ani Science and others. Therefore, it is not surprising that Arabic, Ushul Fiqh is one of the essential requirements that a mujtahid must possess.

Secondly, that this shari'at ummiyyah, meaning to be able to understand it does not need the help of natural sciences such as the science of reckoning, chemistry, physics and others. This is so that the syari'ah is easily understood by all human circles. If to understand this shari'ah require the help of other science like natural science, at least there are two big obstacle to be faced by human generally, that is obstacle in terms of understanding and in execution. Shari'a is easily understood by anyone and from any field of science because it stems to the concept of maslahah (fahuwa ajraa 'ala i'tibari al-maslahah)

\section{CONCLUSION}

The zhahiriyyah school is a school that stores certain texts by forgetting the global objectives of sharia. Among them there are those who are more dominant with the nature of religion, and among them there are those who are dominant in the nature of politics, even though they are all the same in terms of understanding literalism. The Zhahiriyya have been exaggerated in extracting text literalism to bring them to the strange understanding rejected by religion and reason. Zahiriyyah characteristics literal understanding and interpretation in understanding and interpreting texts without seeing things hidden in them, both in illat form and intentions that can be known by profound researchers.

1) Difficult and difficult

2) Arrogant towards their opinions

3) Don't accept different people

4) Kafir people who have different opinions

5) Whatever slander

The Bathiniyyah school is the opposite of the forgotten zhahiriyah school, even deliberately refusing, certain texts. This flow claims that they see the common good and global goals. This flow dares to oppose religious texts brought by the revelation ma`sum, both the Qur'an or al-Sunnah. They reject the text without caring, and freeze it without knowledge and guidance unless they follow the nature of themselves or others who want to make slander against the teachings of truth revealed by God. When they annulled religious texts in the name of human benefits. They claim that from these spies they are not out of the Shari'ah, they defend their intentions and maintain their spirit and substance, even though they do not maintain symbols and forms.

Characteristics of the divine; 1) Superficial understanding of sharia `ah; 2) Dare to think without knowledge; 3) Follow westward. The third characteristic of the bathiniyyah school is to follow the other, west, both capitalism, liberalism or marix, all born in the west. From this they want to impose Western philosophy on the life, western views of religion, the concept of western scularism, and western, social, political, linguistic, and cultural legal theories for us. Some of them said, "we have to eat when they eat, dress when they are dressed, write when they write.

\section{REFERENSI}

[1] Az-Zarkasyi, al-Bahr al-Muhith, Kuwait: Wizarat al-Auqaf wa al-syu'un al-Islamiyyah, 1993, Jilid VI.

[2] Al-Amidi, al-Ihkam fi Ushul al-Ahkam, Muassasah al-Halaby, 1991, Juz IV.

[3] Al-Qarafi, Syarh Tanqih al-Fushul, Maktabah al-Kulliyyah alAzhariyyah, t.th..

[4] Al-Ghazali, al-Mustashfa, Beirut: dar al-Fikr, 1997, Juz I.

[5] Ahmad Raisuni, Nadhariyyat al-Maqashid 'Inda al-Imam al-Syathibi, Beirut: al-

[6] Ahmad Zaid, dalam muhadharah Fiqh Maqashid yang diselenggarakan Syathibi Center, Wisma Nusantara, 13 Agustus 2002.

[7] Abdul Majid Turki, Munadharat fi Ushul al-Syari'ah al-Islamiyyah Baina Ibn Hazm wa al-Baji, Beirut: Dar al-Garb al-Islamy, 1986.

[8] Imam Syathibi, al-Muawafaqat fi Ushul al-Syari'ah, Beirut: Dar alKutub al-Ilmiyyah, t.th., Juz I

[9] Musthafa Said al-Khin, al-Kafi al-Wafi fi Ushul al-Fiqh al-Islamy, Beirut: Muassasah risalah, 2000.

[10] Muhammad Rasyid Ridha, Mukaddimah Kitab al-I'tisham, Juz I.

[11] Muassasah al-Jami'iyyah Liddirasat wan Nasyr wa al-Tauzi’, 1992.

[12] Yusuf Ahmad Muhammad al-Badawy, Maqashid al-Syari'ah 'Inda Ibn Taimiyyah, Yordan: Dar an-Nafais, 2000. 